\title{
TOL̈LHO
}

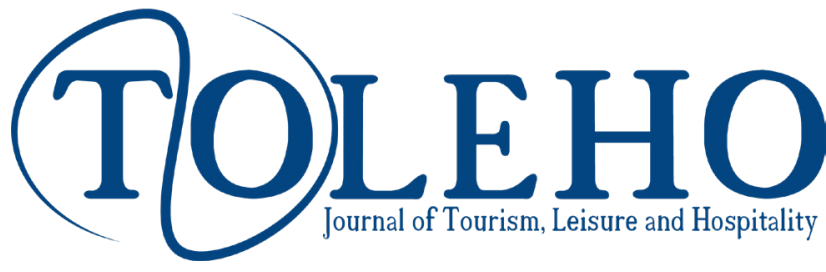

\section{ENFORCEMENT OF TERRITORIALITY PRINCIPLE IN THE CRIMES COMMITTED BY FOREIGN TOURISTS IN TURKEY}

\author{
Eylem Baş, \\ ${ }^{a}$ Department of Criminal and Criminal Procedure Law, Ankara University, Ankara, Turkey. \\ ORCID: 0000-0002-3400-2042 / e-mail:ebas@ankara.edu.tr
}

\begin{tabular}{ll} 
KEYWORDS & ABSTRACT \\
\cline { 2 - 3 } $\begin{array}{l}\text { Foreign tourists } \\
\text { Territoriality principle } \\
\text { Turkish penal code }\end{array}$ & $\begin{array}{l}\text { In Article } 8 \text { of Turkish Penal Code (TPC) No. 5237, entitled "territorial jurisdiction", it is stated that Turkish } \\
\text { laws will be enforced to the crimes committed within the borders of Turkey. Thus, the principle of territoriality }\end{array}$ \\
Turke & is seen to have been adopted. In this context, the principle of territoriality was first reviewed in this study. \\
& However, in order for the principle of territoriality to be enforced, it is necessary to focus on what needs to \\
be interpreted from the country of Turkey. As a matter of fact, the country seems to have two dimensions, \\
real and hypothetical in the field of law. In this way, after focusing on what needs to be interpreted from \\
the country of Turkey, it is necessary to determine what should be interpreted from the "place of offence". \\
Although merely the principle of territoriality was not only adopted by Turkey in the enforcement of criminal \\
laws in terms of the place of the offence, the research was limited to the principle of territoriality. In this \\
context, the study examines how and under what circumstances Turkish laws will be enforced in the crimes \\
committed by foreign tourists in Turkey in accordance with the principle of territoriality.
\end{tabular}

\section{Introduction}

Enforcement of criminal laws based on the place of offence is meant to express where these laws will be enforced based on the crimes committed (Zafer, 2016, p. 668). As a matter of fact, the coercive effect of criminal laws has limitations in terms of the place of the offence (Artuk, Gökcen and Yenidunya, 2014, p. 239). Due to its nature, the power of criminal laws to be mandatory enforces only in certain parts of the world (Ersoy, 2002, p. 39; Toroslu and Toroslu, 2019, p. 76; Yüce, 1982, p. 136). According to Article 8, No. 5237 of the Turkish Penal Code (TPC), Turkish laws are enforced within the territory of Turkey, regardless of who and against whom crimes are committed as a requirement of the principle of territoriality (Koca ve Üzülmez, 2020, p. 799). Therefore, the citizenship of the perpetrator does not matter. What matters here is where the crime was committed (Artuk et al., 2014, p. 239; Centel, Zafer and Cakmut, 2006, p. 124; Dönmezer and Erman, 2016, p. 305; Özgenç, 2020, p. 1009). This arises from the principle of territoriality, as stated in the justification of this article, and from the fact that criminal laws are the result of national sovereignty (Şahin and Özgenç, 2005, p. 102).

The validity of criminal laws in the principle of territoriality is limited to the state. In this context, it cannot be argued that this principle could be enforced for the crimes committed out of the country (Mahmutoğlu and Karadeniz, 2017, p. 104). However, with some regulations arising from both domestic and international law, it is possible to foresee some irresponsibilities by making some exceptions to this situation. In such cases, some limitations of criminal laws are argued for individuals. However, this is not addressed in this study.

It is possible to mention four principles: (1) territoriality, (2) personality, (3) protection and (4) universality, which states can apply in determining the validity of criminal laws in terms of the place of the offence (Ersoy, 2002, p. 39-40; Önder, 1991, p.174). Although Article 8 of the TPC has adopted the territorial principle, it seems that this principle has been bent with some other principles (Toroslu and Toroslu, 2019, p. 76-77). For this reason, the system of "quasi-territoriality" is used as a term to express the new situation in question (Artuk et al., 2014, p. 240; Soyaslan, 2012, p. 154). The principle of territoriality, on its own, is not capable of meeting all needs (Ersoy, 2002, p. 40; Yüce, 1982, p. 138). Because this acceptance leads to the fact that Turkish laws cannot be enforced in any crimes committed outside the country (Öztürk and Erdem, 2020, p. 77). However, it should be noted that although there are principles set by each state, it is seen that the principle predominantly accepted is territoriality (Şahin, 2015, p. 140).

${ }^{*}$ Corresponding Author.

Received 21.02.2021; Received in revised form 07.03.2021; Accepted 10.03.2021 This article is licensed under a Creative Commons Attribution 4.0 International License. e-ISSN: 2687 - 3737 / @ 2021 The Authors. Published by Anadolu University. http://dx.doi.org/10.48119/toleho.884426 
According to the principle of the personality of criminal laws, criminal laws are enforced on citizens. A citizen is subject to the law of the state of which he is a citizen, whether he commits a crime in his state or a foreign state (Demirbaş, 2020, p. 148; Toroslu and Toroslu, 2019, p. 76). In this context, the scope of the principle of territoriality is expanded (Dönmezer and Erman, 2016, p. 305, 333). The principle of protection means that criminal laws will be enforced to the crimes committed against the citizen of the state or the state which set up the law (Yüce, 1982, p. 138). In this context, the important issue is who the crime was committed against. It does not matter where and by whom the crime was committed. However, in the doctrine, it is also seen that the victim's being a citizen of the state is considered within the scope of "passive personality principle" under the principle of the personality (Aydın, 2011, p. 137; Önder, 1991, p. 174; Sahin, 2015, p. 122; Zafer, 2016, p. 685). At the heart of this acceptance, the principle of protection is narrowly interpreted and covers only the crimes committed against the state (Mahmutoğlu and Karadeniz, 2017, p. 122). The fourth is the principle of universality, and according to this principle, criminal laws are enforced to some crimes, no matter where by whom and against whom they are committed (Toroslu and Toroslu, 2019, p. 76).

Furthermore, in addition to these four principles, the doctrine also mentions "substitution jurisdiction" and "principle of sharing jurisdiction". In the case when the conditions in the 3rd subsection of Article 12 of the TPC are valid, the punishment of a foreigner in a foreign country, like Turkey, is qualified as "substitution, in other words, jurisdiction on behalf of another state" (Aydın, 2011, p. 132). In other words, it is valid in the cases when a state which adopts the principles ofterritoriality, personality, protection and universality judge a foreign perpetrator committing a crime in a foreign country against a person from a third state and the committed crime is not covered within the scope of the principle of universality. In this way, the state aims to prevent criminals from committing the crime in other territory and thus to prevent the state from being perceived as the paradise of criminals in the public eye (Zafer, 2016, p. 686-687). The principle of sharing power is the transfer and power-sharing regarding jurisdiction procedure of a criminal initiated in one state in accordance with the contracts that allow the transfer of jurisdiction to another state (Centel et al., 2006, p. 123). However, since this study is limited only to the principle of territoriality, evaluations regarding the crimes committed by foreigners in Turkey will be provided. In this context, the basis of the principle of territoriality will first be reviewed. Besides, since this makes it necessary to focus on what needs to be interpreted from the concepts of "state" "and "the place of offence- the place where the crime was committed" (Artuk et al., 2014, p. 241; Önder, 1991, p. 178), these issues will also be examined.
After that, it will focus on whether the provision of a sentence in a foreign country for a crime committed by a foreign tourist in Turkey is an obstacle to the enforcement of Turkish laws to this foreign tourist.

\section{Basis of the Principle of Territoriality}

Jurisdiction, when used in the strict sense, refers to "making judgments in the courts". However, for a long period, it was used to refer to the "provision of jurisdiction and power of disposition". As a matter of fact, the exercise of jurisdiction, the provision of justice, the punishment and the execution of punishment appear as a signal of the sovereignty of the state. In this context, jurisdiction means the power of the state to establish rules and enforce this rule through its courts (Aydın, 2011, p. 132).

It is the legislator who determines the enforcement area of criminal laws and creates legislation. The legislator may determine his will in this matter in an absolute manner without the limitation of another state or supranational authority. For example, it may accept its jurisdiction for a crime committed in another country or enforce the rules of law established by itself to a citizen of another state. However, the fact that a state accepts its jurisdiction to cover the entire world will lead to the extension of the area in which the state will use its jurisdiction and the increase in its responsibility, the inability to access the evidence of crimes committed in a foreign country, the inability to take the perpetrator to the court, the inability to execute the sentence given to the perpetrator (Dönmezer and Erman, 2016, p. 301303 ), thus it will lead to the inability to provide any benefit in terms of jurisdiction (Yalçın and Köprülü, 2019, p. 109). Besides, this will lead to interference in the internal affairs of other states and an increase in disputes arising from jurisdiction among states (Öztürk and Erdem, 2020, p. 76). Therefore, states must take care of the interests of their sovereignty. Thus, it is seen that states limit the enforcement of their criminal laws in terms of the place of the offense (Koca and Üzülmez, 2020, p. 797; Zafer, 2016, p. 668). It should be noted that states should be careful not to violate the rules applicable to international law, abuse of power, and ensure that the established rules are applicable and beneficial when enforcing criminal laws (Önder, 1991, p. 172).

The main characteristic of criminal laws is that its power is limited to the host country. Because criminal laws can only be enforced in the state where they are legislated. Although there are currently debates on International Criminal Laws along with debates on globalization, the territory where criminal laws are enforced is the country of the state in which it is legislated (Hafızoğulları and Toroslu, 2019, p. 38; Soyaslan, 2012, p. 150). Each state has an area of sovereignty, and in this area, states establish their public order for their benefit. The punishment of a crime committed in the name of ensuring public order arises as a signal of sovereignty. Therefore, it cannot be argued that a state has the authority to 
punish crimes committed all over the world. At the heart of this is the lack of authority of the state, the lack of power and time. In this context, states limit their areas of sovereignty and their power to punish. This limitation is not carried out by regulations in international law, but by regulations in domestic law (Yaşar, Gökcan and Artuç, 2014, p. 325). As a matter of fact, the rules on the enforcement of criminal laws based on the place of the offense are directly the subject of domestic law (Önder, 1991, p. 171-173). Regarding the international criminal affairs, for example, the European Convention on the Extradition of criminals intends to provide operability to these domestic legal rules. For this reason, enforcement of criminal laws based on the place of offense is not the subject of international criminal law (but see. Tezcan, Erdem and Önok, 2019, p. 80), but directly of criminal law (Zafer, 2016, p. 668).

It seems that the principle of territoriality began to be enforced with the emergence of the states caring for their sovereignty because each state has the right of sovereignty in its own country by its nature. Therefore, it does not want to share this right and power with any other party. At the heart of the adoption of this principle is the idea that public order is broken wherever the crime was committed, and that the broken public order could be restored by punishing the perpetrator at the site where the crime was committed (Demirbaș, 2020, p. 148). In this way, it will be possible to talk about the preventive and frightening effect of punishment (Soyaslan, 2012, p. 151). As a matter of fact, the closer the punishment is applied to where the crime is committed, the more useful it is (Artuk et al., 2014, p. 240).

Although it is stated that the social contract is also the source of this principle because, in this way the state punishes those who oppose its common interests, it is not possible to talk about this when the crimes committed by foreign tourists. Foreign tourists are not parties to this agreement (Tezcan et al., 2019, p. 84).

The principle of territoriality acts on the assumption that each individual has to know the laws in which he lives. In this context, the enforcement of the local law where the crime was committed to the perpetrator creates a guarantee for the perpetrator in a sense (Tezcan et al., 2019, p. 85-86). In other words, the perpetrator knows what law to be enforced to him when committing the crime (Soyaslan, 2012, p. 152).

Another reason is that the perpetrator leaves evidence of the crime wherever he has committed the crime. In this context, witnesses at the place of the offense, the tools used in committing a crime, and the evidence of the crime could be given as examples. It also serves the procedural economy. For example, it eliminates the cost of transporting evidence. It is also accepted that it is fairer for the perpetrator to be tried in his preferred country where he committed the crime (Mahmutoğlu and Karadeniz, 2017, p. 104).
For the reasons mentioned above, it is seen that the principle of territoriality is a system adopted and enforced by all states. However, it should be noted that no single principle has been adopted regarding the enforcement of criminal laws in any state. It is seen that the mixed system has been adopted in Turkey (Dönmezer and Erman, 2016, p. 306-308, 332-333).

The principle of territoriality refers to the enforcement of the laws of the country in which the crime is committed, on the one hand. In other words, the states do not interfere with the crimes committed by their citizens in another country. Since the recognition that each state has absolute jurisdiction in their sovereignty prevents interventions that may lead to judicial sovereignty among states, as well as ensuring the protection of the principles of international law (Mahmutoğlu and Karadeniz, 2017, p. 104).

\section{The Concept of "Country" Concerning the Enforcement of the Principle of Territoriality}

In the first sentence of the 1. Paragraph of Article 8 of TPC, it is stated that Turkish laws will be enforced to the crimes committed within the borders of Turkey. In this context, it is necessary to determine where Turkey is located. A country is a part of the Earth where the state has sovereign powers (Mahmutoğlu and Karadeniz, 2017, p. 104, 108). It is seen that Turkey's borders are drawn by international treaties in accordance with the rules of international law (Parlar, 2015, p. 95). As a matter of fact, the problem of where the country is is outside the scope of criminal law and is essentially the subject of international law. because Turkey has various border agreements with its neighbouring states (Önder, 1991, p. 178).

In the field of law, it seems that the country has two dimensions, real and hypothetical (Dönmezer and Erman, 2016, p. 308). Turkey is a land where it uses the rights of sovereignty of the Republic of Turkey, with drawn borders with other neighbouring states, and it owns streams, rivers, lakes, and all kinds of water resources including certain airspace above the dominated land. The land area of the state, its territorial waters and the airspace above its land are called the real country (Demirbaş, 2020, p. 149). Besides, it is stated in the doctrine that the country is classified as horizontal and vertical in real terms, that Turkey's land area and territorial waters should be considered as horizontal and its airspace should be considered as a vertical country (Mahmutoğlu and Karadeniz, 2017, p. 109; Önder, 1991, p. 178). It should be noted that if the crime is committed in Turkish land and airspace and Turkish territorial waters, it is unnecessary to state that the crime will be considered to have been committed in Turkey, and it is not appropriate to say "assumed" in the subparagraph (a) of the 2. paragraph of article 8 of the TPC (Centel et al., 2006, p. 125; Dönmezer and Erman, 2016, p. 309). The reason for that is that, 
according to international law, the country already consists of land, airspace and territorial waters (Hafizoğulları, 2019, p. 39).

As stated in the subparagraph (b), (c) and (d) of the 2. paragraph of article 8 of the TPC, Turkish naval and air war vehicles; and Turkish sea, and air vehicles in the airspace over the high sea, fixed platforms in Turkey's continental shelf or exclusive economic zone are considered as the hypothetical country (Mahmutoğlu and Karadeniz, 2017, p. 109; Yaşar et al., 2014, p. 325).

\subsection{Country in Real Terms}

\subsubsection{Turkish territorial area}

Turkish territorial area covers the places such as any piece of land where its borders are drawn with the borders of other states, inland waters inside any piece of land, and coastal area (Mahmutoğlu and Karadeniz, 2017, p. 109). As a matter of fact, according to Article 4 of the Territorial Waters Law No. 2674 (Turkey), "the waters remaining on the land side of the main lines and the waters of the Gulf are considered as Turkish inland waters. Permanent port facilities are considered part of the coast, and the waters remaining on the land side of the furthest point and the outer ports are considered inland waters". The underground of the land should also be accepted as a territorial area (Yaşar et al., 2014, p. 327). In this context, for example, the crime of sexual harassment committed by a foreign tourist in the underground city of Derinkuyu, located in the Cappadocia region of Turkey, should be considered committed in Turkey.

It should be noted that the territory of the foreign embassy and consulate in Turkey is Turkey's territory, although it is possible to mention the judicial immunity of the officials working in these facilities, as they are located within Turkey's territorial area (Birtek, 2018, p. 108-109; Tezcan et al., 2019, p. 89-90). In this context, the offence of libel committed by a German tourist at the German Embassy in Turkey is considered committed in Turkey according to article 8 of TPC (Hakeri, 2019, p. 90; Yaşar et al., 2014, p. 326-327, fn 186).

\subsubsection{Turkish airspace}

In the subparagraph (a) of article 3 of the Civil Aviation Act No. 2920 (Turkey), it is seen that the airspace is defined as "the country under the sovereignty of the Republic of Turkey and the area over Turkish territorial waters". In Article 4 of the relevant law, it is assumed that the Republic of Turkey has "full and exclusive sovereignty in Turkish airspace". This regulation corresponds to article 1 of the Convention on International Civil Aviation, which is also known as the Chicago Convention of 1944 (Mahmutoğlu and Karadeniz, 2017, p. 110). In other words, the airspace is the area above the Turkish land territory and its territorial waters. The height of the airspace is a controversial issue in the doctrine (Dönmezer and Erman, 2016, p. 313).
As a matter of fact, it is controversial how far the sovereignty of the Criminal Code should be limited in the air today when the space age is in progress (Hafızoğulları and Özen, 2019, p. 40). In this context, some approaches are claiming that the altitude where gravity is effective, or the places where air transport is favourable and the height up to the atmosphere should be considered as state borders (Önder, 1991, p. 183).

In the subparagraph (a) of the 2. paragraph of article 8 of the TPC, it is stated that crimes committed in Turkish airspace will be considered committed in Turkey. In this context, it is seen that there is no distinction between whether a foreign aircraft is a civilian or a combat vehicle (Dönmezer and Erman, 2016, p. 312). However, considering a crime committed in Turkish airspace within Turkey's jurisdiction seems to be controversial (Özbek, Doğan and Bacaksız, 2020, p. 138). For this reason, if the state passed through the airspace is not posed any danger with regards to air transport, it would be the right solution not to mention bout the jurisdiction of Turkey (Mahmutoğlu and Karadeniz, 2017, p. 110). As a matter of fact, it is necessary to focus on the concept of interest in the recognition that aircraft passing in transit in the airspace of the state is within the jurisdiction of the state whose airspace is passed through. It is possible that a crime committed on a plane flying the flag of a foreign state does not disrupt the public order of the state passed through. Even the state passed through may not even know about such crimes committed in their airspace. For the solution of such problems, it is recommended to adopt the flag or landing place principle (Yüce, 1982, p. 143-144). The flag principle grants sovereignty over sea and air vehicles to the registered state whose flag is carried. In this context, the state uses the authority to punish crimes committed in the sea and air vehicles carrying its flag, regardless of where the vehicle is or what the citizenship of the perpetrator or victim is (Tezcan et al., 2019, p. 89).

Itisseen that this was organized with the Convention on Offences and Certain Other Acts Committed on Board aircraft held in Tokyo on 14.9.1963, which Turkey also signed. According to the article 3 of this convention, "the State of registration of the aircraft is competent to exercise jurisdiction over offences and acts committed on board." Besides according to 4 . Article of this convention "A Contracting State which is not the State of registration may not interfere with an aircraft in flight in order to exercise its criminal jurisdiction over an offence committed on board except in the following cases : a) The offence has effect on the territory of such State; b) The offence has been committed by or against a national or permanent resident of such State; c) The offence is against the security of such State; d) The offence consists of a breach of any rules or regulations relating to the flight or manoeuvre of aircraft in force in such State; e) The exercise of jurisdiction is necessary to ensure the observance of any obligation 
of such State under a multilateral international agreement." This convention entered into force in Turkey with the publication of the Law No. 1889 "on our participation in the Tokyo Convention of September 14, 1963 on the crimes committed on aircraft and some other acts" in the Official Gazette No. 15226 dated 4.5.1975.

In the doctrine, the use of jurisdiction in the crimes committed in the airspace of a foreign state, in a civil air vehicle carrying the Turkish flag is still controversial. As a matter of fact, according to some claims, 5271 Code of Criminal Procedure (CCP), 15 should be enforced in such cases. In this context, it is stated that the court of the airport first visited by the vehicle after leaving Turkey is authorized for the crimes committed on the aircraft with the Turkish flag, and therefore act will be enforced (Artuk et al., 2014, p. 251). The same interpretation is accepted in the crimes committed on civilian marine vessels or the crimes committed with these vehicles (Önder, 1991, p. 182). Another interpretation is that the purview of CCP does not pronounce any judgement regarding the place of the offense (Dönmezer and Erman, 2016, p. 316), is important for determining the authority in domestic law and is not valid in international law (Özbek et al., 2020, p. 140). However, in this case, it is necessary to assess whether other principles adopted for the enforcement of criminal laws based on the place of offense could also be enforced (Koca and Üzülmez, 2020, p. 809-810; Mahmutoğlu and Karadeniz, 2017, p. 112). The same is true for the crimes committed on civilian naval vehicles carrying the Turkish flag or the crimes committed on the high sea and outside Turkish territorial waters with these vehicles (Mahmutoğlu and Karadeniz, 2017, p. 112).

\subsubsection{Turkish territorial waters}

Territorial waters can be defined as a sea zone that surrounds the national territory of a state and extends to the high sea (Koca and Üzülmez, 2020, p. 807). According to Article 3 of the United Nations Convention on the Law of the Sea, 1982, it is stated that each state has the right to determine the width of its territorial waters, that this width cannot exceed 12 nautical miles, beginning from the main lines drawn under the relevant convention. In this context, as stated in Article 1 of the territorial waters Law No. 2674, "Turkish territorial waters are included in the country of Turkey. The width of Turkish territorial waters is six nautical miles. For certain seas, the president of the country is authorized to determine the width of territorial waters above six nautical miles, provided that he takes into account all the characteristics associated with those seas and complies with the principle of fairness." Based on this law, the width of territorial waters of Turkey is determined as 6 nautical miles in the Aegean Sea and 12 nautical miles in the Mediterranean and the Black Sea (Artuk et al., 2014, p. 243).

If a crime is committed in Turkish territorial waters, whose borders are drawn in this way, the crime is considered to have been committed in Turkey in accordance with the subparagraph (b) of the 2. paragraph of article 8 of the TPC (Koca and Üzülmez, 2020, p. 808; Yüce, 1982, p. 142). For example, even the crime committed by a foreign tourist on a foreign cruise ship in Turkish territorial waters to another foreign tourist will be considered committed in Turkey and the relevant Turkish laws will be enforced (Artuk et al., 2014, p. 246; Yaşar et al., 2014, p. 328).

Considering the importance of territorial waters in international transport, it seems that the jurisdiction of states is restricted by international law (Artuk et al., 2014, p. 246; Mahmutoğlu and Karadeniz, 2017, p. 112-113). In accordance with the United Nations on the Law of the Sea of 1982, all states are recognized to have the right of free passage for their ships, as long as they give no harm in their territorial waters (Mahmutoğlu and Karadeniz, 2017, p. 114; Önder, 1991, p. 180-181). In the Geneva Convention on Territorial Waters and Contiguous Zone of 1958, it was recognized that the crimes to be committed on the cruising ships carrying passengers or commercial goods and the crimes to be committed with the use of these marine vessels are within the jurisdiction of the country whose flag is on the board (Mahmutoğlu and Karadeniz, 2017, p. 114). In such cases, the following criteria established in Article 19 of Convention on the Territorial Sea and the Contiguous Zone need to be met for the coastal state to interfere in the crime: "(a) If the consequences of the crime extend to the coastal State; or (b) If the crime is of a kind to disturb the peace of the country or the good order of the territorial sea; (c) If the assistance of the local authorities has been requested by the captain of the ship or by the consul of the country whose flag the ship flies; or (d) If it is necessary for the suppression of illicit traffic in narcotic drugs." (United Nations, 1964, p. 6). However, it should be noted that Turkey is not a party to this agreement. It seems that Article does not include any exceptions in the use of Turkish territorial waters in Article 8 of TPC (Akbulut, 2019, p. 151). This is rightly criticised as it is considered contrary to Turkey's international obligations and international law (Özbek et al., 2020, p.138).

According to Article 8 of the TPC, if a crime is committed in the territorial waters or air space of a foreign country with an air or marine vessel, except combat vehicles, Turkish laws could not be enforced considering that the crime was committed in Turkey. In such cases, other principles, if exist, could be applied to enforce Turkish laws (Öztürk and Erdem, 2020, p. 80; Tezcan et al., 2019, p. 88).

\subsection{Hypothetical Country}

\subsubsection{High sea and airspace above it}

According to the 1st Article of Convention on the High Seas, "the term "high seas" means all parts of the Sea that are not included in the territorial sea or the internal waters of a state" (United Nations, 1964, p. 81). However, it should be noted that Turkey is not a 
party to this agreement. Since no one could mention that the high sea and the airspace above it belong to any state, in this case, the principle of territoriality cannot be argued (Artuk et al., 2014, p. 239-240, fn 199 ) and the principle of the flag could be claimed to be valid for this case (Yaşar et al., 2014, p. 327). At the heart of this acceptance is the desire to prevent any crime committed on the high seas from going unpunished (Mahmutoğlu and Karadeniz, 2017, p. 115). In this context, if a foreign tourist intentionally wounds another person on the Turkish plane, for example, on this plane crossing the airspace over the high sea, the crime will be considered committed in Turkey and Article 86 regarding the "intentional injury" of the TPC will be enforced to the case. If a foreign tourist intentionally kills another person on a marine vessel, for example, on a marine vessel cruising on the high sea when flying the Turkish flag, the crime will be considered committed in Turkey and Article 81 regarding the "intentional killing" of the TPC will be enforced to the case.

In the collision of the Turkish cargo ship, Bozkurt, and the French merchant-ship, Lotus, in the high sea at 5-6 nautical miles off the island of Lesbos on 2.8.1926, eight of the crew of the ship, Bozkurt, which sank were lost, and Lotus brought the saved captain and a few crew of Bozkurt ship to Istanbul. Desmons, the French captain of Lotus, was tried in Istanbul for the collision and deaths that occurred and sentenced to 80 days in prison and a fine on 15.9.1926. Since the collision took place on the high sea, France stated that Turkey did not have jurisdiction, but Turkey rejected this note and proposed taking the case to the international Permanent Court of Justice in the Hague. By the court on the date of 7.9.1927, France's defence was rejected if resulted in the death of some Turkish citizens, and Turkey's jurisdiction was found to comply with international laws, Bozkurt ship was considered to be a territorial extension of Turkey on the high seas. As the deaths took place on the Turkish Bozkurt ship, it was stated that Turkey could judge the criminals considering the hypothetical country principle (Demirbaş, 2020, p. 150; Dönmezer and Erman, 2016, p. 303, fn 951).

However, as stated in Article 2 of the "the International Convention for the unification of certain rules relating to penal jurisdiction in matters of collision or other incidents of navigation", signed in Brussels on 10.5.1952. in terms of the conflicts on the high seas, it is stated that the flag principle applies to the personnel of each marine vessel (Tezcan, 1995, p. 267-271; Yüce, 1982, p. 143). It is also accepted in Article 11 of the Geneva Convention on the High Seas of 1958 and 1. Paragraph of Article 97 of the 1982 Convention on the High Sea. Thus, it differentiated from the adjudication of the international Permanent Court of Justice (Artuk et al., 2014, p. 248, fn. 229). It could be claimed that acceptance of the flown flag principle complied with Article 8 of the TPC because a crime was committed with these vehicles (Koca and Üzülmez, 2020, p. 810).

\subsubsection{Turkish Naval and Air Combat Vehicles}

In the subparagraph (c) of the 2. Paragraph of Article 8 of the TPC, if the crime is committed in "Turkish naval and air combat vehicles or with these vehicles", the crime is considered committed in Turkey, even when these vehicles are in the territory of another country state (Dönmezer and Erman, 2015, p. 313; Hafızoğulları and Özen, 2019, p. 40).

As a rule, for the crimes committed on foreign naval combat vehicles, the laws of the state whose flag is flying on the board enforced in the jurisdiction (Yaşar et al., 2014, p. 328). As a matter of fact, naval combat vehicles represent the military power of the state and demonstrate its sovereignty. As such naval vehicles are considered a part of the hypothetical country they belong to, even when the perpetrator of a crime committed in Turkey takes sanctuary to a foreign sea warship approaching the coastal state, the perpetrator will not be directly extradited to the coastal state, and the agreement for Extradition of criminals will apply (Artuk et al., 2014, p. 243; Mahmutoğlu and Karadeniz, 2017, p. 113; Özbek et al., 2020, p. 137). However, unless there is a special regulation regarding the immunity and jurisdiction for the combat vehicles (Yalçın and Köprülü, 2019, p. 113), a crime committed to the staff of that vehicle by a citizen of that coastal state, the crimes committed among the people on that vehicle who are not staff of that vehicle and the crimes committed to the citizens of the coastal state out of that vehicle are considered to be within the jurisdiction authority of the coastal state (Dönmezer and Erman, 2016, p. 315; Koca and Üzülmez, 2020, p. 807; but see. Artuk et al., 2014, p. 243). For example, if one of the crews of a Russian warship kills someone in Istanbul, where he went to rest, the crime is considered committed in Turkey, and Turkish laws are enforced (Yaşar et al., 2014, p. 329).

There is no difference between the fact that naval or air vehicles other than combat vehicles belong to a state and belong to private persons (Soyaslan, 2012, p. 153). However, although only combat naval vehicles are stated in Article 8 of the TPC when official naval vehicles are in the territorial waters of other countries and operate under official mandate under Article 22 and 23 of the Territorial Waters and Contiguous Zone Convention of 1958, they have legal immunity even if they are in the territorial waters of other countries (Mahmutoğlu and Karadeniz, 2017, p. 114).

\subsubsection{Fixed platforms built in Turkey's continental} shelf or exclusive economic zone

According to article 55 of United Nations Convention on the Law of the Sea "The exclusive economic zone is an area beyond and adjacent to the territorial sea, subject to the specific legal regime established in this Part, under which the rights and jurisdiction of the coastal State and the rights and freedoms of other States are governed by the relevant provisions of this Convention." Also, according to article 57 of this convention "The exclusive economic zone shall not extend beyond 
200 nautical miles from the baselines from which the breadth of the territorial sea is measured."

According to article 76 of this Convention "the continental shelf of a coastal State comprises the seabed and subsoil of the submarine areas that extend beyond its territorial sea throughout the natural extension of its land territory to the outer edge of the continental margin, or to a distance of 200 nautical miles from the baselines from which the breadth of the territorial sea is measured where the outer edge of the continental margin does not extend up to that distance." Also, According to Article of this Convention "The coastal State exercises over the continental shelf sovereign rights to explore it and exploit its natural resources" In international law, it is recognized that some economic interests of the state exist on its continental shelf as an extension of its mainland (Hafızoğulları and Özen, 2019, p. 40).

The "Convention for the suppression of unlawful acts against the safety of maritime navigation", held in Rome on March 1 to 10,1988 , was signed by Turkey on the protocol "Prevention of illegal acts committed against the safety of maritime navigation" and "Prevention of illegal acts committed against the safety of fixed platforms on the Continental Shelf". Thus, the acceptance of crimes committed on or against the fixed platforms established on Turkey's continental shelf or exclusive economic zone as committed in Turkey is stated in the subparagraph (d) of article 8 of the TPC (see also. Şahin and Özgenç, 2005 , p. 102). In this context, for example, if crimes are committed in the facilities established for fishing in the continental shelf zone of Turkey, the crime is considered to have been committed in Turkey.

\section{Place of Offense}

Determining the place of offence is important in determining whether the state has jurisdiction and where the trial for the crime committed will be held (Yalçın and Köprülü, 2019, p. 107). As stated in the 1. clause of the 1. Paragraph of Article 8 of TPC, "Turkish Laws" should be enforced to any crime committed in Turkey. In this context, TPC includes special penal laws, codes containing crime and punishment provisions, laws related to criminal procedure and execution (Yaşar et al., 2014, p. 327).

To decide if a crime has been committed within Turkey or not, it is important to focus on the term the "place of offence" to make interpretation clear. Because according to article 7 of European Convention on Extradition "The requested Party may refuse to extradite a person claimed for an offence which is regarded by its law as having been committed in whole or in part in its territory or a place treated as its territory." Besides, under the Rome Statute, the International Criminal Court has secondary jurisdiction over the court of the state where the crime was committed. If a trial is avoided by the state that has jurisdiction over the committed crime, or if a trial is impossible in that state, it tries a case (Mahmutoğulları and Karadeniz, 2017, p. 117).
Whereas crimes causing tangible consequences consists of the relationship between criminal conduct, crime result and casuality, those which do not cause any crime result are considered as criminal conduct. If the criminal conduct occurs in the form of exercise, it means the action has come true; if it is not exercised and remains in the form of intention, it means neglect. For example, the crime of "deliberate killing" defined in Article 81 of TPC is an offence causing consequences. Death is the consequence of the crime committed in this context (Toroslu and Toroslu, 2019, p. 131-133). The offence of theft defined in Article 141 of TPC is a crime of conduct and has crime results (Koca and Üzülmez, 2020 , p. 800). The crime is completed by taking the portable property from its location without the consent of its owner.

In terms of determining the place of the offense, there is no problem if the place of offense is within the borders of Turkey for the crimes causing consequences. The same applies only to crimes of conduct. In the first case, the crime is considered to have been committed where the crime of conduct and crime results occurred, and in the second case, where the crime of conduct occurred (Toroslu and Toroslu, 2019, p. 78; Ersoy, 2002, p. 41). However, if the judicial or political boundaries between the place where the crime of conduct performed and where the crime results occurred are different, they are treated as distance crimes (Zafer, 1990, p. 32; Artuk et al., 2014, p. 254). There are different theories in the doctrine of how to practice. Although distance crimes are mainly used in the doctrine, there are also views suggesting that it is much more appropriate to use the term "cross-border crimes" (Ersoy, 2002, p.42), "border-crossing crimes" (Mahmutoğlu and Karadeniz, 2017, p. 118, fn. 62), "transborder crimes" (Önder, 1991, p. 185) or "longdistance crimes" (Yüce, 1982, p. 145) to express this situation.

Distance crimes concern criminal law in terms of the place of offense based on the principle of territoriality, but they concern criminal procedure law in terms of determination of national authority and district of offense within the country (Zafer, 1990, p. 32). However, this study will evaluate it considering within the scope of the principle of territoriality.

For distance crimes, the murder of someone in Turkey with a bomb sent from Germany, or the murder of someone in Bulgaria with a bullet fired from the Turkish side of the Turkey/Bulgaria border could be given as examples (Toroslu and Toroslu, 2019 , p. 78). In the first case, although the criminal conduct was carried out in another country, the crime result was in Turkey's border, so it is named as the "distance from outside to inside crime", and in the second case, the criminal conduct was carried out in Turkey's border, but the crime result occurred within the border of Bulgaria, so it is named as the "distance from inside to outside crime". If there is an 
agreement between the two states for such cases, it will be resolved in accordance with the provisions of this agreement, if not, in accordance with the provisions of judicial assistance (Aydın, 2011, 135).

According to the theory, which argues that criminal conduct should be based on the determination of the place of offense in distance crimes, the place of criminal conduct is accepted as the place of the offense. According to this view, the evidence is often available where the criminal conduct was carried out, and therefore, it is much easier to access the evidence (Mahmutoğlu and Karadeniz, 2017, p. 120). of course, here crime conduct means the execution actions of the crime and the preparatory actions are not meant. In addition, whether the result of crime will occur or not depends on coincidence (Centel et al., 2006, p. 115-117). By committing the crime, the perpetrator has already rebelled against the order protected by the legislator. The crime is accepted to have been committed when the perpetrator carries out criminal conduct (Önder, 1991, p. 187). The criminal will of the perpetrator is also in question as soon as he performs criminal conduct.

In addition, according to this view, since the place of criminal conduct is unique by its nature, it is considered to be the most corresponding one to the principle of territoriality. Therefore, the place of criminal conduct is accepted as the place offense. Considering that each crime may not bear consequences, it is more consistent to base the crime on the place of criminal conduct. Besides, in terms of press offences, there could be one single place of criminal conduct, but the crime results could be seen in more than one place. Therefore, it is beneficial to base the crime on the place of criminal conduct. However, ignoring this theory could fail to satisfy the identification of the place of the offense. Similarly, as no action is visible in ommission offences, it is not easy to identify the place and time of the offense (Artuk et al., 2014, p. 254-255). It is also criticized for accepting the result as a trivial element (Yaşar et al., 2014, p. 330).

According to a theory that gives superiority to the crime result, the crime should also be considered committed where the crime bear consequences. Because public order is disrupted where the crime result occurs, if the result does not occur, it does not matter if the crime was conducted or not (Mahmutoğlu and Karadeniz, 2017, p. 120). In terms of offences against persons, it is stated that most of the evidence is in the place of offense and therefore the crime should be considered to have been committed wherever the crime bear consequences. However, this view is criticized arguing that the perpetrator committed the crime knowing and taking into account the laws of the place of the offense (Yaşar et al., 2014, p. 330). In addition, this theory ignores the crimes which bear no consequences (Artuk et al., 2014, 257).

According to mixed theory, a crime should be considered committed where the crime of conduct is performed, continues, and the crime bears consequences. For this reason, according to Yüce (1982, p. 145), this theory is also expressed as "everywhere theory". It is seen that this view is more preferred and adopted than other views. As a matter of fact, it is more appropriate for criminal law to consider both the place of offense and the place where committed crime bears consequences as the place of offense for the crime committed. Because public order is broken where both the criminal conduct is committed and the crime bears consequences. According to the mixed view, for example, in the case when a foreign tourist in Turkey defrauding someone in Germany, or vice versa, the crime is considered committed in Turkey and the Turkish laws are enforced.

It is seen that mixed theory is adopted with the 1 . paragraph of article 8 of TPC (Şahin, 2015, p. 119). It should be noted that if this theory is not adopted, problems will arise. As a matter of fact, if the state where the criminal conduct was performed adopts the crime result theory, and the state where the crime bears consequences adopts the criminal conduct theory, the committed crime will go unpunished and the expected benefit from criminal justice will not be obtained (Mahmutoğlu ve Karadeniz, 2017, p. 121; Önder, 1991, p. 176-177). However, the adoption of a mixed theory by more than one state can also lead to legal conflicts in terms of jurisdiction among these states (Zafer, 1990, p. 34). It is argued that this problem can also be overcome by accepting the state that first lay hands on the event as the authorized state (Yaşar et al., 2014, p. 330-331). However, in practice, it seems that such problems have been resolved by international conventions or by the International Court of Justice (Zafer, 2016, p. 672).

Besides, here concerning what needs to be understood from the crime result, the doctrine also mentions the concept of the "main result" and "the close result", and both should be accepted within the scope of the crime result. If a bullet fired from Turkey's side hits someone in Bulgaria, but this person dies in Greece because of this act, the criminal conduct occurs in Turkey, the close result occurs in Bulgaria, and the main result occurs in Greece. If the mixed theory is adopted, it is accepted that the crime was committed in three countries. Although the doctrine states that the crime should be considered committed where the criminal conduct was first committed and bore consequences, by mentioning the "hit or effect theory" in this case, and in the case mentioned above, the crime was accepted to have been committed in Bulgaria, but anyway this theory has been criticized. As a matter of fact, it is possible to solve the place of offence by taking into account either the criminal conduct or the crime result theory (Artuk et al., 2014, p. 257; Özbek et al., 2020, p. 142). In addition, The International Court of Justice interprets the crime result broadly and accepts the close result within the scope of the place of the offense. 
"Transit offences" are also mentioned in the doctrine as besides distance offences. According to this, the criminal conduct that causes the crime is committed in a foreign country, and the crime result occurs in another country. However, in these crimes, there may be no violation of the legally protected asset or interest of the country which is passed in transit through (Önder, 1991, p. 194). As an example, illegal immigrants are transported from Syria to Greece, but they are transported through Turkey's airspace. In such a case, as stated in article 79 of TPC, it should be assumed that the crime was committed in Turkey since the legal issues of Turkey were violated with the crime of migrant trafficking (Özbek, 2020, p. 158). However, we cannot interpret every case as that the crime was committed in the country which is passed in transit (Akbulut, 2019, p. 159; Mahmutoğlu and Karadeniz, 2017, p. 129). As a matter of fact, in a case in which an insulting letter passed in transit through Turkey from Syria to Germany, we cannot accept that the place of offence is Turkey claiming that it disrupted public order of Turkey (Yüce, 1982, p. 146). However, the doctrine also argues that in terms of transit crimes, the crime could be accepted to have been committed also in the transit country in every case (Hakeri, 2019, p. 87).

Article 8 of TPC mentions "committing the act partially or completely in Turkey", and it also mentions "occurrence of crime result in Turkey" at the same time, which is not appropriate. The correct expression is either "the commitment of the offence partially or completely in Turkey" or "the commitment of the criminal conduct partially or completely in Turkey, or the occurrence of crime result in Turkey". In this regard, Article 8 of TPC needs further regulations. If the criminal conduct can be divided into parts, considering the partial or complete commitment of the crime in Turkey, accepting that any part of a crime was committed in Turkey should be considered sufficient to accept the crime committed in Turkey (Mahmutoğlu and Karadeniz, 2017, p. 119; Yașar, et. al., 2014, p. 331). Considering the Court of Cassation practices regarding the enforcement of Article 8 of TPC, for example, according to the judgment of the Court of Cassation's 12's Criminal Chamber 2012/28360 register number and 2013/1040 judgment number and dated 15.01.2013, if cultural heritages in Turkey were illegally taken abroad by a foreign tourist, the crime was accepted to have been committed in Turkey, since the crime had been completed at the time of smuggling of the heritages violating the valid laws as stated in the first paragraph of Article 68 of the Cultural and Natural Heritage Protection Act No 2863 (Artuk et al., 2014, p. 264).

With regards to continuing crimes, violation of the relevant law should continue for a certain time. In this context, as regulated in Article 109 of TPC, the offence of "deprivation of liberty" is a continuing crime. For example, let's take the following case; a person is kidnapped from Turkey by a foreign tourist and taken to Bulgaria, or a person is kidnapped in Germany by a German citizen and released in Turkey. In this case, if the kidnapped person is transferred from Turkey and released, for example, in Iran, the crime will be considered committed in Turkey (Yaşar et al., 2014, 331-332). In a sense, the crime is assumed to have been committed in the countries where the continuity of the crime occurs, and each state takes into account the part of the crime committed in its own country to judge (Artuk et al., 2014, p. 259). However, the doctrine also argues that only where the interruption occurred should be accepted as the place of the offense (Özbek et al., 2020, p. 143).

If Turkey is the place of crimes aggravated by the result, it should again be considered that the crime was committed in Turkey (Akbulut, 2019, p.158). Considering successive offence, if one of the successive offences is committed in Turkey, the crime should be assumed to have been committed in Turkey (Zafer, 2016, p. 673). For example, if one of the foreign tourists on a cruise flying Turkish flag again commits the crime of theft against another person on the cruise on two successive days, and if the offence on the first day is committed in Turkish territorial waters and the second-day offence was committed in Greek territorial waters, the crime will again be considered committed in Turkey (Mahmutoğlu and Karadeniz, 2017, p. 124; Yaşar et al., 2014, p.331-332). However, for crimes committed outside Turkey to be evaluated within the scope of successive offences, the conditions of the principles of personality, protection or universality must be met (Koca and Üzülmez, 2020, p. 804).

Considering the omission crimes, the crime should be considered committed where the perpetrator avoids it, even though he has to take action, or where the crime result occurs (Yalçın and Köprülü, 2019, p. 109). For example, a foreign tourist who is a German citizen decides to kill his child by not feeding him and starts starving his child from the first day he comes for a vacation in Antalya, and then returns to his country and child dies in Germany. In this case, the German tourist stops fulfilling his feeding duty in Antalya, and therefore, the crime should be considered to have been committed in Turkey. When the just opposite of this case is taken, for example, if a foreign tourist who is a German citizen stops feeding his child in Germany and then comes to Turkey and the death of a child occurs in Turkey, it is again accepted that the crime was committed in Turkey.

Regarding "habitual offender" in the (f) subparagraph of article 6 of TPC, it is defined as "any person who, within a one-year period, at more than two different times, commits the same basic, aggravated or lesser version of the crime with intention". The fact that this definition is expressed based on the offender rather than the crime itself reveals the approach towards the law of criminal execution. In this context, more than two crimes do 
not have to be committed in Turkey within a year to be able to talk about habitual offender (but see. Akbulut, 2019, p. 164; Artuk et al., 2014, p. 259260 , fn. 275). As a matter of fact, habitual criminals are subject to execution regime unique to habitual offenders. The reason for that is that the perpetrator is dangerous. The fact that the perpetrator committed a part of the crime abroad does not eliminate the danger of the perpetrator (Mahmutoğlu and Karadeniz, 2017, p. 128).

Considering the jointly committed offence, if a part or result of the criminal conduct that causes a crime occurs in Turkey, the offence should again be considered committed in Turkey. In this case, Turkish laws will be enforced on those who assist or instigate the crime committed in Turkey from a foreign country (Koca and Üzülmez, 2020, p. 804). However, for this purpose, the person who instigates or assists must be present in Turkey. If these people are not present in Turkey, Turkey will reclaim for the extradition of the perpetrator (Özgenç, 2020, p. 1010; Şahin, 2015, p. 120-121). However, for example if the crime was committed by a German citizen in Germany, but a foreign tourist who is a French citizen was assisted or abetted to commit this offence from Turkey, nobody can claim any longer that the crime was committed in Turkey (Artuk et al., 2014, p. 260; Centel et al., 2006, p. 122; Zafer, 2016, p. 675). However, the doctrine also argues that the crime should be accepted as being committed in Turkey (Mahmutoğlu and Karadeniz, 2017, p. 126; Yüce, 1982, p. 146). However, the way to follow here is to return the aider or instigator in Turkey to a foreign country through extradition of criminals, but if the aider or instigator is a Turkish citizen, the citizen cannot be extradited, so articles 10,11 or 13 of the TPC should be enforced in such cases (Demirbaș, 2020, p. 151).

Considering the attempted crime, if a different result is obtained as a consequence of the criminal conduct committed by the perpetrator, the place of criminal conduct and this different crime result is accepted as the place of the offence within the scope of the mixed theory. However, if no crime result emerges, whereas this is not what is intended by the perpetrator, then the place of criminal conduct should now be considered the place of the offense (Mahmutoğlu and Karadeniz, 2017, p. 126). Although the doctrine also suggests that a crime result should be expected and that the cases when no crime results are obtained should also be as the place of the offence (Özbek et al., 2020, p. 143; Yüce, 1982, p. 146), Article 8 of TPC poses an obstacle to this view (Dönmezer and Erman, 2016, p. 327; Koca and Üzülmez, 2020, p. 802; Hakeri, 2019, p. 86; Zafer, 2016, p. 671).

Since it is not possible to talk about a physical environment in the crimes committed through the Internet, it should be noted that the place of offence needs further consideration. In this context, it seems that the issue of the place of offense for such crimes is very controversial. As a matter of fact, it is suggested that these crimes will be considered committed anywhere in the world (Artuk et al., 2014, p. 261-262; Özgenç, 2020, p. 110, fn. 3). However, this admission will lead to an expansion of Turkey's jurisdiction in the crimes committed and will go against the logic of the trial (Dönmezer and Erman, 2016, p. 328; Sahin, 2015, p. 121-122). For this reason, it is useful to adopt a separate and open regulation for the crimes committed through the internet (İçel and Ünver, 2012, p. 445). Until this regulation is made, almost all crimes committed through the internet are considered distance crimes (Öztürk and Erdem, 2020, p. 87-89), Article 8 of TPC could be enforced in such cases. In this context, for example, if criminal content is uploaded to the internet from Turkey, relevant Turkish laws will be enforced. It does not matter if the perpetrator uploads the content through a foreign server. If the crime result occurs in Turkey, it is noted that the crime was committed in Turkey (Yașar et al., 2014, 331-332). As a matter of fact, it is seen that the Supreme Court agreed with that (19th Criminal Chamber of the Court of Cassation, 2018/2119 Register Number and 2013/1040 Judgment Number K. 2018/5852 and dated 9.5.2018).

\section{Convicted in a Foreign Country for a Crime Committed in Turkey}

According to article 9 of TPC, entitled "Conviction in a Foreign Country", "Any person who is convicted in a foreign country for an offence committed in Turkey shall be subject to retrial in Turkey." Article 9 functions as the signal that the principle of territoriality has been adopted (Parlar, 2015, p. 95; Yaşar et al., 2014, p. 325). Besides, if this person is tried in a foreign country for a crime committed in Turkey, and even if the sentence given against him has been executed, he will be tried again in Turkey. With this article, the aim is to prevent criminals from going unpunished in a foreign country for a crime committed in Turkey or to prevent a lighter sentence. However, a retrial of a person in both a foreign country and Turkey for a crime committed is criticized in the doctrine based on the doctrine as it is against the "non-bis in idem" principle (Artuk et al., 2014, p. 267; Dönmezer and Erman, 2016, p. 315). It should be noted that this principle does not have validity between states, since the provision given by the court of one state cannot bind another (Akbulut, 2019, p. 165; Önder, 1991, p. 226; Özbek et al., 2020, 145). Besides, as stated in the 2. paragraph of article 53 of the European Convention on the International Validity of Criminal judgments, it is accepted that this principle may not be adopted in the cases when the jurisdiction of the states arises in accordance with the principle of territoriality. As a matter of fact, Turkey is a party to this agreement and the "law on the ratification and implementation of the European Convention on the International Value of criminal judgments" was published in the Official Gazette 
No. 15877 dated 13.3.1977. However, what is fair and lawful is that the problems arising in relation to non-bis in idem principle are solved with Article 16 of TPC, entitled "Deduction from the Penalty" which states that "Any time spent in custody, detention, under arrest or serving a prison sentence in a foreign country in respect of an offence, irrespective of where the offence was committed, shall be deducted from the penalty to be given for the same criminal offence in Turkey" (Özbek et al., 2020, p. 146).

Article 9 of TPC envisaged differentiation between Turkish citizen and a foreigner committing a crime in Turkey and sentenced in a foreign country for that crime in favour of the foreigner. However, as this is considered contrary to the "principle of equality", relevant revisions were made on Article and the differentiation between a Turkish citizen and foreigner was repealed (see also. Şahin and Özgenç, 2005 , p. 103).19 In this context, even if the person who has committed a crime in Turkey, tried in a foreign country for this crime and sentenced for this crime, and he is tried again in Turkey for the same crime without any permission or adjudgement. For example, in terms of a sexual assault committed by a foreign tourist coming to Turkey from France against a German citizen in Antalya, this person will be tried again in Turkey, even if he is tried in France and convicted for this crime (Koca and Üzülmez, 2020, p. 811).

Despite the fact that article 9 of TPC states a person who has been convicted in a foreign country, it is not necessary to wait for the sentence to be given about the perpetrator in order for the perpetrator to be tried in Turkey for the same crime. Even if the perpetrator is tried abroad, he will be tried again in Turkey. In this context, it is necessary to interpret the statement "convicted" as "even if convicted" in accordance with the purposeful interpretation. It should also be noted that the sentence given in a foreign country does not matter whether it is an acquittal or a conviction. In this case, the perpetrator will still be tried in Turkey (Parlar, 2015, p. 98; Yaşar et al., 2014, p. 335).

\section{Conclusion}

In terms of the offense committed in Turkey by foreigners, Turkish laws are enforced as stated in Article 8 of the TPC. This is a consequence of the territoriality principle as well as the fact that criminal laws are the result of national sovereignty. If the act committed in Turkey does not constitute a crime according to Turkish law, even if it constitutes a crime according to the laws of another country, Turkish laws cannot be enforced on these foreign tourists due to the nature of the act committed. However, if the acts committed by foreign tourists in Turkey constitute a crime according to Turkish law and if they do not constitute a crime according to the laws of the country in which they are citizens, the crime is considered to have been committed in Turkey and Turkish law are enforced to such crimes.
In order for the crime to be accepted as being committed in Turkey, it must have been committed in the real or hypothetical country of Turkey. The real country consists of a territorial field, territorial waters and airspace over these territories, the hypothetical country consists of Turkish air and sea combat vessels, Turkish sea and land vessels sailing on the Turkish High seas and over Turkish territorial waters and fixed platforms in Turkish continental shelf and exclusive economic zone

In the subparagraph (a) of Paragraph 2 of TPC, it is stated that the offences committed in Turkish airspace and territorial waters will be considered committed in Turkey. In this context, it is seen that there is no distinction between whether foreign air and sea vehicles are civilians or war vehicles. However, considering a crime committed in Turkish airspace within Turkey's jurisdiction is a problematic issue. It is seen that such cases are regulated in the Convention on Offences and Certain Other Acts Committed on Board of aircraft held in Tokyo on 14.9.1963, in which Turkey is also a party. As a matter of fact, this convention mentions the cases in which a crime is committed on an air vehicle in the airspace of a foreign country or a crime committed with such air vehicles, and jurisdiction of such crimes according to the laws of the state whose flag is carried on the air vehicle. However, the convention also mentions the power of intervention of the country whose airspace is passed in transit considering the exceptional cases as mentioned in this study. As for Turkish airspace, this problem appears to be valid for foreign vessels in Turkish territorial waters. Again, although it seems that this problem has also been resolved by the Convention on the Territorial Sea and the Contiguous Zone, it should be noted that Turkey is not a party to this agreement.

As stated in Article 8 of the TPC, if the criminal conduct is partially or completely committed in Turkey, or if the crime result occurred in Turkey, it is considered as a crime committed in Turkey, and it seems that the mixed theory has been adopted in relation to determining the place of the offense. In this context, it is determined whether the crime committed by a foreign tourist was committed in Turkey and then the Turkish laws are enforced to the committed crime. The fact that a foreign tourist is tried and convicted in a foreign country for a crime committed in Turkey, is not an obstacle to the retrial of that person in line with Turkish laws in Turkey. However, in such cases, the time spent in custody, detention or conviction in a foreign country will be deducted from the punishment that will be given in Turkey for the same crime.

\section{References}

Akbulut, B. (2019). Ceza Hukuku Genel Hükümler (6th Ed.). Ankara: Adalet Yayınevi.

Artuk, M.E., Gökcen, A. and Yenidünya, A.C. (2014). Türk Ceza Kanunu Şerhi, Volume I (2nd Ed.). Ankara: Adalet Yayınevi. 
Aydın, D. (2011). Ceza Kanunlarının Yer Yönünden Uygulanması. Türkiye Barolar Birliği Dergisi, 94, pp. 131-148.

Birtek, F. (2018). Ceza Hukuku Genel Hükümler Temel Bilgiler (6th Ed.). Ankara: Adalet Yayınevi.

Centel, N., Zafer, H. and Çakmut, Ö. (2006). Türk Ceza Hukukuna Giriş (4th Ed.). İstanbul: Beta Yayıncılık.

Demirbaş, T. (2020). Ceza Hukuku Genel Hükümler (15th Ed.). Ankara: Seçkin Yayıncılık.

Dönmezer, S. and Erman, S. (2016). Nazari ve Tatbiki Ceza Hukuku, Volume I (14th Ed.). Ankara: Seçkin Yayıncılık.

Ersoy, Y. (2002). Ceza Hukuku Genel Hükümler. Ankara: İmaj Yayınevi.

Hafizoğulları, Z. and Özen, M. (2019). Türk Ceza Hukuku Genel Hükümler (12th Ed.). Ankara: Savaş Yayınları.

Hafizoğulları, Z. and Toroslu, N. (2019). Türk Ceza Hukuku Genel Hükümler (12th Ed.). Ankara: US-A Yayıncılık.

Hakeri, H. (2019). Ceza Hukuku Genel Hükümler (22nd Ed.). Ankara: Adalet Yayınevi.

İçel, K. and Ünver, Y. (2012). Kitle Iletişim Hukuku (9th Ed.). İstanbul: Beta Yayıncılık.

Koca, M. and Üzülmez, İ. (2020). Türk Ceza Hukuku Genel Hükümler (13th Ed.). Ankara: Seçkin Yayıncılık.

Mahmutoğlu, F.S. and Karadeniz, S. (2017). Türk Ceza Kanunu Genel Hükümler Şerhi (1st Ed.). İstanbul: Beta Yayıncılık.

Önder, A. (1991). Ceza Hukuku Genel Hükümler, Volume I (1st Ed.). İstanbul: Beta Yayıncılık.

Özbek, V.Ö., Doğan, K. and Bacaksız, P. (2020). Türk Ceza Hukuku Genel Hükümler (11th Ed.). Ankara: Seçkin Yayıncılık.

Özen, M. (2019). Öğreti ve Uygulama Işığında Ceza Hukuku Genel Hükümler (3rd Ed.). Ankara: Adalet Yayınevi.

Özgenç, I. (2020). Türk Ceza Hukuku Genel Hükümler (16th Ed.). Ankara: Seçkin Yayıncılık.

Öztürk, B. and Erdem, M.R. (2020). Uygulamalı Ceza Hukuku ve Güvenlik Tedbirleri Hukuku (20th Ed.). Ankara: Seçkin Yayıncılık.

Parlar, A. (2015). Türk Ceza Kanunu Şerhi, Volume I (2nd Ed.). Ankara: Bilge Yayınevi.

Şahin,

Şahin, C. and Özgenç, i. (2005). Türk Ceza Hukuku Gazi Külliyatı (1st Ed.). Ankara: Seçkin Yayıncılık.

Şahin, i. (2015). Ceza Kanunlarının Yer Bakımından Uygulanması ve Türk Ceza Kanununda Esas Alınan Illkeler. Erciyes Üniversitesi Hukuk Fakültesi Dergisi, 10 (1), 107-144.

Soyaslan, D. (2012). Ceza Hukuku Genel Hükümler (4th Ed.). Ankara: Yetkin Yayınları.

Tezcan, D. (1995). Bozkurt-Lotus Davasının Uluslararası Hukuktaki Önemi ve Yeri. DEÜ Atatürk Illkeleri ve Inkılap Tarihi Enstitüsü Çağdaş Türkiye Tarihi Araştırmaları Dergisi, 2 (4-5), 267-274.

Tezcan, D., Erdem, M.R. and Önok, M. (2019). Uluslararası Ceza Hukuku (5th Ed.). Ankara: Seçkin Yayıncılık.

Toroslu, N. and Toroslu, H. (2019). Ceza Hukuku Genel Kısım (24th Ed.). Ankara: Savaş Yayınevi.

United Nations. (1964). Treaty Series, Volume 450. New York: United Nations.

Yalçın, T. and Köprülü, T. (2019). Ceza Hukuku Genel Hükümler Uygulamalı Çalışmaları (6th Ed.). Ankara: Savaş Yayınevi.

Yaşar, O., Gökcan, H.T. and Artuç, M. (2014). Yorumlu -
Uygulamalı Türk Ceza Kanunu, Volume I. Ankara: Seçkin Yayıncılık.

Yüce, T.T. (1982). Ceza Hukuku Dersleri, Volume I. Manisa: Şafak Basım ve Yayınevi.

Zafer, H. (1990). Mesafe Suçu. Argumentum, 1990 (1), 32-35.

Zafer, H. (2016). Ceza Hukuku Genel Hükümler. İstanbul: Beta Yayıncılık.

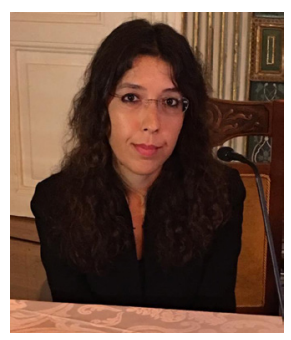

Eylem Baş, received her Ph.D. degree in Public Law from Ankara University Graduate School of Social Sciences, Turkey in 2020. She is currently working at Ankara University Faculty of Law. Her research interests include criminal law, criminal procedure law and criminology.

ORCID: 0000-0002-3400-2042 